\title{
Carcinoembryonic antigen in serum in diseases of the liver and pancreas
}

\author{
S. K. KHOO AND I. R. MACKAY
}

From the Clinical Research Unit of The Walter and Eliza Hall Institute of Medical Research and The Royal Melbourne Hospital, Victoria 3050, Australia

SYNOPSIS Carcinoembryonic antigen (CEA) was measured in whole serum and in serum extracted with perchloric acid by microradioimmunoassay in patients with benign and malignant diseases $A$ of the liver and pancreas. The level of detectability was $5 \mathrm{ng}$ per $\mathrm{ml}$. This level or greater was present $\triangle$ in the serum of $50 \%$ of patients with chronic diffuse liver disease, $64 \%$ with pancreatitis, $94 \%$ 윽 with cancer of the digestive system, and 3\% of controls. The incidence of levels of CEA of $5 \mathrm{ng} / \mathrm{ml} \mathrm{or}-$ more differed for various categories of chronic liver disease: from $22 \%$ in active chronic hepatitis, $46 \%$ in primary biliary cirrhosis, $63 \%$ in hepatoma, $78 \%$ in cryptogenic cirrhosis, and $88 \%$ in alcoholic cirrhosis; levels of CEA correlated with degrees of impairment of liver function as judged by bromsulphalein retention and serum levels of alkaline phosphatase and transaminase. In pancreatitis, $64 \%$ of cases had levels of CEA ranging from 5 to $20 \mathrm{ng} / \mathrm{ml}$ and in cancer of the pancreas $94 \%$ had levels above $5 \mathrm{ng} / \mathrm{ml}$ and $50 \%$ above $20 \mathrm{ng} / \mathrm{ml}$.

Carcinoembryonic antigen (CEA) in serum was originally held to be specific for cancer of the digestive system (Gold and Freedman, 1965a, 1965b), but CEA-like activity has been reported in serum in various non-neoplastic diseases, particularly of the liver and pancreas (Lo Gerfo, Krupey, and Hansen, 1971; Moore, Kupchik, Marcon, and Zamcheck, 1971 ; Moore, Dhar, Zamcheck, Keeley, Gottlieb, and Kupchik, 1972; Krupey, Wilson, Freedman, and Gold, 1972; Warner, Khoo, MacSween, Bankhurst, and Mackay, 1973). Information is available on the relationship of the extent and spread of cancer, and its histological type, to the appearance of detectable CEA in serum. Thus Laurence, Stevens, Bettelheim, Darcy, Leese, Turberville, Alexander, Johns, and Munro Neville (1972) have reported a progressive increase in frequency of positive assays with spread of cancer of the colon and rectum, stomach, pancreas, bronchus, and breast; for example, the incidence of positive results in colo-rectal cancer increased from 13 of 29 patients with Dukes' stage A, through 22 of 29 patients with Dukes' stage B, to 20 of 20 patients with post-Dukes' stage C. Zamcheck, Moore, Dhar, and Kupchik (1972) reported similarly, citing an equivalent rise in the incidence of positive tests for

Keceived for publication 3 May 1973.
CEA in patients with colonic cancer from $19 \%, \stackrel{\varrho}{\overrightarrow{7}}$ through $53 \%$ to $100 \%$; equivalent findings were $\frac{0}{3}$ reported in a joint investigation (1972) on CEA in colonic cancer. Also, the amount of CEA detected was shown to be quantitatively greater when cancer had disseminated (Zamcheck et al, 1972; Laurence? et al, 1972; Warner et al, 1973). However there did $\frac{5}{3}$ not appear to be any association between morphological differentiation or histological type of the tumour and the detection of CEA in serum according to Laurence et al (1972), and both squamous cell 윽 carcinoma and adenocarcinoma of the female $D$ reproductive tract were equally capable of resulting in raised CEA levels (Khoo and Mackay, 1973).

The present study, using microradioimmunoassay of CEA in whole serum, examines the association of CEA-like activity in serum of patients with chronic $\mathrm{W}$ disease of the liver and pancreas and relates levels $\widetilde{O}$ of CEA to diagnostic subtypes and functional status $\theta$ of the liver. For brevity, 'CEA' will be used instead of 'CEA-like activity', recognizing that CEA may? represent various components with different physicochemical properties.

\section{Materials and Methods}

OUTLINE OF STUDY

Levels of CEA in patients with diseases of the liver 
and pancreas were compared with those in healthy persons, miscellaneous patients in hospital ('hospital controls'), and patients with cancer of the digestive system. The specificity of the assay on whole serum was assessed by reassay of positive sera after extraction with perchloric acid. Levels of CEA were correlated with functional indices of liver disease including bromsulphalein retention (BSP), and levels of serum glutamic oxaloacetic transaminase (GOT), alkaline phosphatase (AP), and bilirubin. Chi square analysis was used to test differences for statistical significance.

\section{PATIENTS}

The study comprised 505 patients, grouped as follows. (a) Liver disease (131), including 115 with diffuse parenchymal disease and 16 with hepatoma complicating cirrhosis, diagnosed histologically; the former 115 were subgrouped, on the basis of results of biochemical tests, autoimmune serological studies, and liver biopsy (Mackay, 1971), into alcoholic cirrhosis (35), active chronic hepatitis (58), cryptogenic cirrhosis (9), and primary biliary cirrhosis (13). (b) Pancreatic disease (30), including 16 with pancreatic cancer diagnosed at operation and 14 with acute pancreatitis or chronic relapsing pancreatitis diagnosed by clinical findings and serum amylase tests. (c) Healthy persons (130), including 30 adults aged 18-23 years in known good health, and 100 blood donors whose health status was not directly assessed by interview or examination. $(d)$ 'Hospital controls' (100), including 25 with uterovaginal prolapse and 75 with cardiac, vascular, and psychiatric disorders, aged from 40 to 85 years. (e) Cancer of digestive system (138) with histological confirmation in all.

RADIOIMMUNOASSAY OF CEA

Carcinoembryonic antigen was measured by the competitive inhibition radioimmunoassay described by MacSween, Warner, Bankhurst, and Mackay (1972) and MacSween, Warner, and Mackay (1973), using purified CEA and goat antiserum to CEA provided by $\mathrm{Dr}$ P. Gold, Montreal. Samples $(2-20 \mu \mathrm{g})$ of CEA were labelled with ${ }^{125} \mathrm{I}$. Several weeks after iodination, the labelled antigen became less precipitable, and the non-precipitable component was removed by gel filtration on Sephadex G-200. Twenty-five $\mu$ l of patient's serum was mixed with $25 \mu \mathrm{l}$ of either a $1 \times 10^{-5}$ or $5 \times 10^{-6}$ dilution of goat antiserum to CEA; the tubes were held for two hours at $37^{\circ} \mathrm{C}$ and then overnight at $4^{\circ} \mathrm{C} ; 50 \mu l$ of ${ }^{125}$ I CEA (concentration $1 \mathrm{ng} / \mathrm{ml}$ ) was then added and the tubes were again held for two hours at $37^{\circ} \mathrm{C}$ and overnight at $4^{\circ} \mathrm{C}$. Antigen-antibody complexes were precipitated with $100 \mu \mathrm{l}$ of rabbit antiserum to goat gamma globulin in a dilution of $1 \times 10^{-1}$ or $2 \times 10^{-2}$. Each assay had three control systems, as follows: (1) pooled normal human serum and $3 \%$ bovine serum albumin in $0.01 \mathrm{M}$ tris buffer replaced in duplicate tubes the goat antiserum to CEA; (2) normal human serum replaced in duplicate tubes the test serum; (3) a standard inhibition curve was constructed by adding known amounts per ml of CEA diluted in normal human serum. Under the conditions of our assay, the lowest amount of CEA detectable was $3 \mathrm{ng}$ per $\mathrm{ml}$; for the expression of results, the lower limit for positivity was taken as $5 \mathrm{ng}$ per $\mathrm{ml}$.

The following modification of the standard procedure of extraction of CEA from serum with perchloric acid was developed for small volumes of serum so as to minimize dilutional effects. Of $4 \mathrm{M}$ perchloric acid, $0.1 \mathrm{ml}$ was slowly added to $0.3 \mathrm{ml}$ of serum in a tube agitated in a Vortex mixer and the supernatant, after being held for one hour at $4^{\circ} \mathrm{C}$ and centrifuged at $4000 \mathrm{~g}$ for 10 minutes, was dialysed against repeated changes of distilled water for 48 hours; the retentate was tested by radioimmunoassay for carcinoembryonic antigen.

BIOCHEMICAL INDICES OF LIVER DISEASE Standard biochemical tests of liver function were performed by automated techniques in the Department of Biochemistry of the Royal Melbourne Hospital. Upper limits of normal ascertained from panels of healthy controls were for BSP retention, $10 \%$ of a $5 \mathrm{mg}$ per $\mathrm{kg}$ dose injected intravenously 45 minutes beforehand, for serum GOT, 40 International Units (IU) per 1, for serum AP, $13 \mathrm{King}$ Armstrong (KA) units per $100 \mathrm{ml}$, and for serum biliribin, $1.0 \mathrm{mg}$ per $100 \mathrm{ml}$. Only results of biochemical tests performed on sera taken within seven days of obtaining sera for CEA estimation were considered.

\section{Results}

OVERALL INCIDENCE OF CEA IN SERUM (TABLE I) Of the 230 sera from healthy persons and hospital controls, seven $(3 \%)$ contained CEA and in six the level was low, 5-10 ng/ml; four were from blood donors and three from hospital controls diagnosed as cardiac failure, cerebral haemorrhage, and hysteria, respectively. Of the 129 sera from patients with non-malignant diseases of the liver (115) and pancreas (14), CEA was detected in 66 (51\%) but levels were mostly low, between 5 and $20 \mathrm{ng} / \mathrm{ml}$. For 138 sera from patients with cancer of the digestive system, CEA was detected in 127 (92\%), and in some $45 \%$ the level exceeded $20 \mathrm{ng} / \mathrm{ml}$. 


\begin{tabular}{|c|c|c|c|c|}
\hline \multirow[t]{2}{*}{ Category and No. of Subjects } & \multicolumn{3}{|c|}{ No. of Cases with CEA in Serum $(n g / m l)$} & \multirow{2}{*}{$\begin{array}{l}\text { Percentage of Cases with } \\
\text { Levels of } C E A>5 \mathrm{ng} / \mathrm{ml}\end{array}$} \\
\hline & $5-10$ & $11-20$ & $>20$ & \\
\hline Young healthy subjects $(30)$ & $\mathbf{0}$ & 0 & 0 & 0 \\
\hline Blood donors (100) & 4 & 0 & $\mathbf{0}$ & 4 \\
\hline Hospital patients (100) & 2 & 1 & 0 & 3 \\
\hline Diffuse liver disease (115) & 20 & 23 & 14 & 50 \\
\hline Pancreatitis (14) & 3 & 6 & 0 & 64 \\
\hline Cancer of digestive system $(138)^{1}$ & 31 & 34 & 62 & 92 \\
\hline
\end{tabular}

Table I Carcinoembryonic antigen in serum in healthy persons, hospital patients, liver disease, pancreatic disease, and $\vec{\circ}$ digestive system cancer

${ }^{1}$ Including colon (91), stomach (18), oesophagus (4), pancreas (20), bile duct and gall bladder (5)

CARCINOEMBRYONIC ANTIGEN IN SPECIFIC DISEASES OF THE LIVER AND PANCREAS

The incidence of positive results for CEA in serum differed for the four subtypes of chronic liver disease, being lowest in active chronic hepatitis $(22 \%)$, intermediate in primary biliary cirrhosis $(46 \%)$, and highest in cryptogenic (78\%) and alcoholic cirrhosis $(88 \%)$; moreover only in cryptogenic cirrhosis and alcoholic cirrhosis was there a substantial incidence $(22-23 \%)$ of values over $20 \mathrm{ng} / \mathrm{ml}$. The differences in incidence of positive results between the groups with alcoholic and cryptogenic cirrhosis, and those with active chronic hepatitis and primary biliary cirrhosis, were highly significant $(\mathrm{P}<0.005)$. For the 16 patients with cirrhosis and hepatoma the incidence approached that in alcoholic and cryptogenic cirrhosis, $63 \%$ having detectable CEA and $13 \%$ having levels exceeding $20 \mathrm{ng} / \mathrm{ml}$.

Of the 14 patients with acute or chronic pancreatitis, $64 \%$ had detectable levels but in no case did the level exceed $20 \mathrm{ng} / \mathrm{ml}$, and of the 16 patients with cancer of the pancreas, $94 \%$ had detectable levels and $50 \%$ had levels greater than $20 \mathrm{ng} / \mathrm{ml}$.

EFFECT OF PERCHLORIC ACID EXTRACTION OF CEA FROM SERUM

For 51 sera which gave a positive result $(5 \mathrm{ng} / \mathrm{ml})$ in the assay on whole serum, CEA was extracted with $\overrightarrow{0}$ perchloric acid; most sera remained positive but levels were lower (table II). Loss of CEA activity occurred particularly with sera from patients with primary biliary cirrhosis and pancreatitis; CEA became undetectable in seven of 13 such sera after extraction. Overall there was about a $25 \%$ loss of CEA activity in sera after extraction and loss $\varrho$ of activity tended to be complete with pre-extraction $\overrightarrow{\overrightarrow{0}}$ levels between 5 and $10 \mathrm{ng} / \mathrm{ml}$. Activity of CEA in 3 whole serum was presumably identical with that in extracted serum, the lower levels after extraction being attributable to dilution.

\begin{tabular}{|c|c|c|c|c|c|c|c|c|}
\hline \multirow[t]{3}{*}{ Category of Disease } & \multicolumn{4}{|c|}{$C E A$ in Whole Serum } & \multicolumn{4}{|c|}{$\begin{array}{l}C E A \text { in Serum before }{ }^{1} \text { and after }{ }^{2} \\
\text { Extraction with Perchloric Acid }\end{array}$} \\
\hline & \multirow[t]{2}{*}{$\begin{array}{l}\text { No. of } \\
\text { Patients }\end{array}$} & \multicolumn{3}{|c|}{$\begin{array}{l}\text { No. of Cases with } \\
\text { Serum Levels }(\mathrm{ng} / \mathrm{ml})\end{array}$} & \multirow[t]{2}{*}{$\begin{array}{l}\text { No. of } \\
\text { Sera tested }\end{array}$} & \multicolumn{3}{|c|}{$\begin{array}{l}\text { No. of Cases with } \\
\text { Serum Levels }(\mathrm{ng} / \mathrm{ml})\end{array}$} \\
\hline & & $>5$ & $>10$ & $>20$ & & $>5$ & $>10$ & $>20$ \\
\hline Active chronic hepatitis & 58 & $\begin{array}{l}13 \\
(22 \%)\end{array}$ & $\begin{array}{c}7 \\
(12 \%)\end{array}$ & $\begin{array}{l}4 \\
(7 \%)\end{array}$ & 13 & $\begin{array}{l}13^{1} \\
13^{2}\end{array}$ & $\begin{array}{l}7^{1} \\
3^{2}\end{array}$ & $\begin{array}{l}4^{1} \\
0^{2}\end{array}$ \\
\hline Cryptogenic cirrhosis & 9 & $\begin{array}{c}7 \\
(78 \%)\end{array}$ & $\begin{array}{l}5 \\
(55 \%)\end{array}$ & $(22 \%)$ & 7 & $\begin{array}{l}7^{1} \\
7^{2}\end{array}$ & $5^{1}$ & $\begin{array}{l}2^{1} \\
0^{2}\end{array}$ \\
\hline Alcoholic cirrhosis & 35 & $(88 \%)$ & 21 & $\begin{array}{l}8 \\
(23 \%)\end{array}$ & 18 & $\begin{array}{l}18^{1} \\
16^{2}\end{array}$ & $\begin{array}{r}14^{1} \\
8^{2}\end{array}$ & $\begin{array}{l}7^{1} \\
0^{2}\end{array}$ \\
\hline Primary biliary cirrhosis & 13 & $\begin{array}{c}6 \\
(46 \%)\end{array}$ & $(31 \%)$ & $(0 \%)$ & 5 & $2^{2}$ & $\begin{array}{l}3^{1} \\
2^{2}\end{array}$ & $\begin{array}{l}0^{2} \\
0^{2}\end{array}$ \\
\hline Hepatoma & 16 & $\begin{array}{l}10 \\
(63 \%)\end{array}$ & $\begin{array}{c}6 \\
\left(38^{\circ}\right)\end{array}$ & $\left.\frac{2}{\left(13^{\circ} \%\right.}\right)$ & & & & \\
\hline Acute or chronic pancreatitis & 14 & $\begin{array}{l}9 \\
(64 \%)\end{array}$ & $\begin{array}{l}6 \\
(43 \%)\end{array}$ & $\begin{array}{l}0 \\
(0 \%)\end{array}$ & 8 & $\begin{array}{l}8^{1} \\
4^{2}\end{array}$ & $\begin{array}{l}7^{1} \\
3^{2}\end{array}$ & $\begin{array}{l}4^{2} \\
1^{2}\end{array}$ \\
\hline Carcinoma of pancreas & 16 & $\begin{array}{l}15 \\
(94 \%)\end{array}$ & $\begin{array}{l}10 \\
(62 \%)\end{array}$ & $\begin{array}{c}8 \\
(50 \%)\end{array}$ & & & & \\
\hline
\end{tabular}

Table II Carcinoembyronic antigen in serum in diseases of the liver and pancreas 
CEA VALUES (ng/DI SERUM)

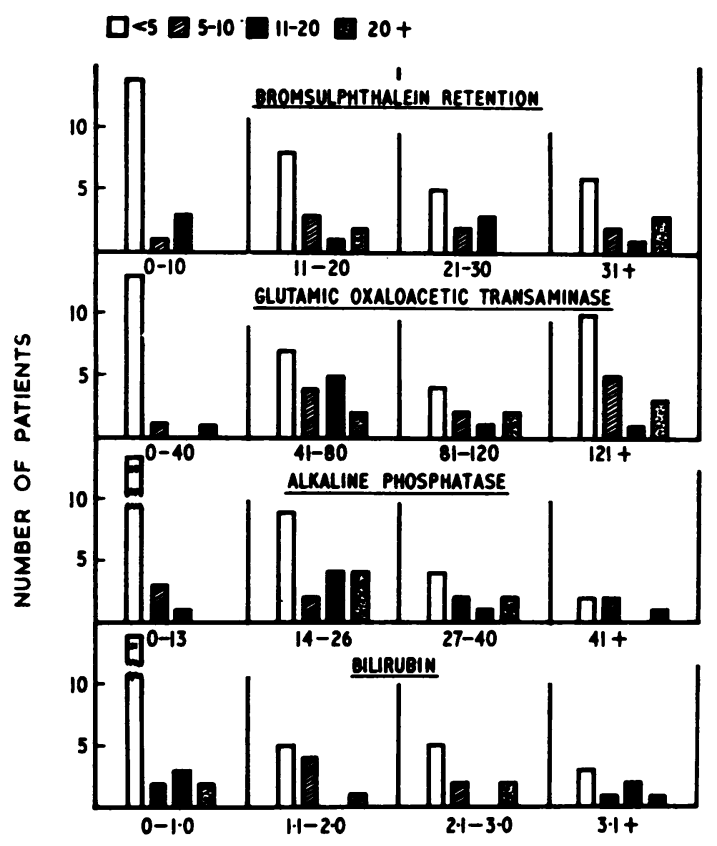

Fig Relation of levels of CEA in serum and functional impairment in diffuse liver disease.

\section{CARCINOEMBRYONIC ANTIGEN AND LIVER} FUNCTION

Tests of BSP retention and serum levels of GOT, AP, and bilirubin were classified either as 'normal' or 'abnormal' if the result was beyond the upper limit of normal. For this analysis, patients were grouped according to whether the level of CEA in whole serum was below or above $10 \mathrm{ng} / \mathrm{ml}$. In the four tests considered, the incidence of levels of CEA above $10 \mathrm{ng} / \mathrm{ml}$ was significantly greater in the presence of abnormality of liver function (table III), as assessed by BSP retention ( $\mathrm{P}<0.005$ ), serum AP $(P<0.001)$, and serum GOT $(P<0.02)$. There was a trend for higher levels of CEA to be associated with more advanced abnormalities of most of the functional indices (fig 1).

\section{Discussion}

Radioimmunoassay for CEA in serum is being assessed as a diagnostic procedure for cancer of the gastrointestinal tract, pancreas, lung, breast, and to a lesser degree of the female reproductive system and other organs (Thomson, Krupey, Freedman, and Gold, 1969; Moore et al, 1971; Lo Gerfo et al, 1971 ; Reynoso, Chu, Holyoke, Cohen, Nemoto, Wang, Chuang, Guinan, and Murphy, 1972; Zamcheck et al, 1972; Warner et al, 1973).

The different immunoassays for CEA in common use include the 'Thomson-Gold' assay (Thomson et al, 1969) in which extracted serum is tested and CEA-antiCEA complexes are precipitated with ammonium sulphate, the 'Z-gel' assay of Lo Gerfo et al (1971) in which extracted serum is tested and complexes are precipitated by zirconyl gel, and the 'double antibody' assay in which whole serum is tested and complexes are precipitated by antibody to goat serum. For both the Thomson-Gold and the Z-gel assay, a level of $2.5 \mathrm{ng} / \mathrm{ml}$ has been defined as a positive result (Thomson et al, 1969; Lo Gerfo et al, 1971), and there was an overall correlation of 83 to $86 \%$ between them (Sorokin, Kupchik, Zamcheck, and Dhar, 1972). Laurence et al (1972) equated a result of $12.5 \mathrm{ng} / \mathrm{ml}$ of CEA by their 'double antibody' method with $2.5 \mathrm{ng} / \mathrm{ml}$ detected by the 'Z-gel' assay. Our present double antibody microradioimmunoassay detected $3 \mathrm{ng} / \mathrm{ml}$, but we used a 'cut-off' level of $5 \mathrm{ng} / \mathrm{ml}$. The cut-off level could be further raised to decrease 'background', but sensitivity is lost (Joint National Cancer Institute of Canada/American Cancer Society Investigation, 1972).

\begin{tabular}{|c|c|c|c|c|c|c|}
\hline \multicolumn{2}{|c|}{ Liver Functional Index ${ }^{1}$} & \multicolumn{4}{|c|}{ Cases with CEA $>10 \mathrm{ng}$ per $\mathrm{ml}$} & \multirow{2}{*}{$\begin{array}{l}\text { Significance } \\
\text { of Difference }\end{array}$} \\
\hline & & $\begin{array}{l}\text { Active } \\
\text { Chronic } \\
\text { Hepatitis }\end{array}$ & Cirrhosis $^{2}$ & $\begin{array}{l}\text { Primary } \\
\text { Biliary } \\
\text { Cirrhosis }\end{array}$ & Total & \\
\hline $\begin{array}{l}\text { BSP retention } \\
(10 \%)\end{array}$ & $\begin{array}{l}\text { Normal } \\
\text { Abnormal }\end{array}$ & $\begin{array}{l}0 / 32 \\
5 / 20\end{array}$ & $\begin{array}{l}0 / 3 \\
8 / 12\end{array}$ & $\begin{array}{l}3 / 3 \\
1 / 4\end{array}$ & $\begin{array}{r}3 / 38 \\
14 / 36\end{array}$ & $<0.005$ \\
\hline $\begin{array}{l}\text { Serum GOT } \\
(40 \mathrm{IU} / 1)\end{array}$ & $\begin{array}{l}\text { Normal } \\
\text { Abnormal }\end{array}$ & $\begin{array}{l}0 / 10 \\
5 / 23\end{array}$ & $\begin{array}{l}1 / 5 \\
11 / 17\end{array}$ & $\overline{2 / 5}$ & $\begin{array}{r}1 / 15 \\
18 / 45\end{array}$ & $<0.02$ \\
\hline $\begin{array}{l}\text { Serum AP } \\
(13 \mathrm{KAU} / 100 \mathrm{ml})\end{array}$ & $\begin{array}{l}\text { Normal } \\
\text { Abnormal }\end{array}$ & $\begin{array}{l}0 / 18 \\
6 / 12\end{array}$ & $\begin{array}{l}1 / 5 \\
8 / 15\end{array}$ & $\begin{array}{l}0 / 1 \\
3 / 6\end{array}$ & $\begin{array}{r}1 / 24 \\
17 / 33\end{array}$ & $<0.001$ \\
\hline $\begin{array}{l}\text { Serum bilirubin } \\
(1 \mathrm{mg} / 100 \mathrm{ml})\end{array}$ & $\begin{array}{l}\text { Normal } \\
\text { Abnormal }\end{array}$ & $\begin{array}{l}2 / 19 \\
3 / 11\end{array}$ & $\begin{array}{l}3 / 8 \\
3 / 11\end{array}$ & $\begin{array}{l}0 / 1 \\
3 / 4\end{array}$ & $\begin{array}{l}5 / 28 \\
9 / 26\end{array}$ & n.s. \\
\hline
\end{tabular}

Table III Functional indices of the liver and incidence of positive results for CEA $>10 \mathrm{ng}$ per $\mathrm{ml}$

${ }^{2}$ Upper limit of normal in brackets; ${ }^{2}$ Cirrhosis = alcoholic or cryptogenic cirrhosis; n.s. = not significant 
Clinical interpretation of a positive test for CEA must allow for its presence in benign diseases of the liver and pancreas. Weakly positive tests for CEA could be indicative of either cancer or diffuse liver disease, but strongly positive results, particularly with normal or only mildly altered biochemical tests of liver function, would indicate cancer either in an extrahepatic site or metastatic in the liver. Carcinoma of the pancreas is not readily differentiated from pancreatitis on the basis of CEA levels, but higher levels are more indicative of cancer. The value of CEA assay in the detection of hepatoma is slight because of the high frequency of positive results in cirrhosis.

A high incidence (some $50 \%$ ) of CEA in patients with benign diseases of the liver and pancreas was reported by Lo Gerfo et al (1971) and Moore et al (1971), although levels were lower than those in patients with cancer of the digestive system. Levels of CEA exceeding $2.5 \mathrm{ng} / \mathrm{ml}$ were detected in 40 of 88 patients with alcoholic liver disease but in none of 14 patients with non-alcoholic liver disease, and positive results correlated with alcoholic hyalin, hydropic degeneration, and fat in the liver (Moore et al, 1972). We found levels of CEA above 5 $\mathrm{ng} / \mathrm{ml}$ in various forms of diffuse parenchymal liver disease, but the incidence and serum levels differed considerably according to the pathogenetic subtype, being greatest in alcoholic and cryptogenic cirrhosis and least in active chronic hepatitis. The magnitude of the CEA level correlated with the severity of the liver disease, as indicated by conventional tests of liver function, and the higher incidence of positive results in alcoholic and cryptogenic cirrhosis could be attributed to a greater impairment of function in these diseases.

The frequent detection of CEA in benign disease of the liver and pancreas poses the question of the specificity of the assay. Is CEA in effect being detected? Comparison of our results before and after extraction of CEA from serum with perchloric acid in patients with benign liver and pancreatic diseases indicates that positive tests for CEA remained even after extraction in 42 of 51 analyses. There was a moderate reduction in CEA level with sera extracted with perchloric acid, as compared with whole serum levels. The degree of reduction correlated with the dilution necessary for extraction, and the loss of CEA activity was therefore attributed to this. Other explanations would be interference with CEA activity by acid treatment, and loss of CEA activity via the dialysis membrane. Finally, in certain conditions, some of the CEA activity measured in our present assay might represent cross-reactive molecular configurations different from those measured in other assays; for example, in cases of 'active' ulcerative colitis, extraction and dialysis eliminated CEA-like activity detected in untreated serum (Khoo, Hunt, and Mackay, 1973).

The reason for elevated levels of CEA or CEA-line substances in benign liver diseases remains uncertaik, as metabolism of CEA in the liver is yet to be known, and the following possibilities exist.

Production of CEA could accompany cellular regeneration in the liver; in cancer, CEA has been demonstrated on the glycocalyx of the tumour cell surface (Gold, Gold, and Freedman, 1968).

Inflammation in the liver could give rise to glycoproteins with CEA-like activity.

Impaired liver function could result in failure of excretion of small amounts of CEA possibly produced under normal conditions.

We note that only small amounts of CEA are $\stackrel{\partial}{O}$ extractable from normal and cirrhotic livers, much 웅 less than amounts demonstrable in colonic cancer (Kupchik and Zamcheck, 1972; Khoo, Warner, Lie, $\subseteq$ and Mackay, 1973); however, there is said to be identical immunological reactivity between extracts $\vec{\theta}$ of liver, extracts from hepatic metastases of colonic $\omega$ cancer, and sera of cirrhotic patients (Kupchik and Zamcheck, 1972). Although our present results suggest that functional impairment of the liver is an important cause of raised levels of CEA in cirrhosis, other causes must be invoked to account for the finding in pancreatitis, and effects of inflammatory activity and cellular damage and regeneration remain to be assessed. Also the physicochemical nature of these CEA-reactive substances in non-neoplastic diseases of the liver and pancreas remains to be characterized.

We thank Dr N. L. Warner for his interest in the work and the supply of ${ }^{125}$ I-CEA for the microradioimmunoassay, Dr P. Gold for the supply of purified CEA and antiserum, Dr Moses Yu of 욱 Singapore for kindly referring sera of patients with hepatoma, and Mrs D. Goriup and Miss H. Campbell for their technical assistance. The work was supported by grants from the National Health o and Medical Research Council of Australia and the Queensland Cancer Fund.

References

Gold, P., and Freedman, S. O. (1965a). Demonstration of tumorspecific antigens in human colonic carcinomata by immunological tolerance and absorption techniques. J. exp. Med., 121, 439-462.

Gold, P., and Freedman, S. O. (1965b). Specific carcinoembryonic antigens of the human digestive system. J. exp. Med., 122, 467-481.

Gold, P., Gold, M., and Freedman, S. O. (1968). Cellular location of $\stackrel{\mathbb{Q}}{\varrho}$ carcinoembryonic antigens of the human digestive system. $\underset{<}{C}$
Cancer Res., 28, 1331-1334.

Joint National Cancer Institute of Canada/American Cancer Society Investigation (1972). A collaborative study of a test for $\frac{0}{0}$ 
carcinoembryonic antigen (CEA) in the sera of patients with carcinoma of the colon and rectum. Canad. med. Ass. J., 107, 25-33.

Khoo, S. K., Hunt, P. S., and Mackay, I. R. (1973). Studies of carcinoembryonic antigen in whole and extracted serum in ulcerative colitis. Gut, in press.

Khoo, S. K., and Mackay, E. V. (1973). Carcinoembryonic antigen in cancer of the female reproductive system: its detection in whole serum by microradioimmunoassay. Aust. N.Z. J. Obstet. Gynaec., in press.

Khoo, S. K., Warner, N. L., Lie, J. T., and Mackay, I. R. (1973). Carcinoembryonic antigenic activity of tissue extracts: a quantitative study of malignant and benign neoplasms, cirrhotic liver, normal adult and fetal organs. Int. J. Cancer, II.

Krupey, J., Wilson, T., Freedman, S. O., and Gold, P. (1972). The preparation of purified carcinoembryonic antigen of the human digestive system from large quantities of tumor tissue. Immunochemistry, 9, 617-622.

Kupchik, H. Z., and Zamcheck, N. (1972). Carcinoembryonic antigen(s) in liver disease. II. Isolation from human cirrhotic liver and serum and from normal liver. Gastroenterology, 63, 95-101.

Laurence, D. J. R., Stevens, V., Bettelheim, R., Darcy, D., Leese, C., Turberville, C., Alexander, P., Johns, E. W., and Munro Neville, A. (1972). Role of plasma carcinoembryonic antigen in the diagnosis of gastrointestinal, mammary, and bronchial carcinoma. Brit. med. J., 3, 605-608.

Lo Gerfo, P., Krupey, J., and Hansen, H. J. (1971). Demonstration of an antigen common to several varieties of neoplasia. New Engl. J.Med., 285, 138-141.

Mackay, 1. R. (1971). Cirrhosis and other diseases of the liver. In Immunological Diseases, 2nd ed, edited by M. Samter, D. W. Talmage, B. Rose, W. B. Sherman, and J. H. Vaughan, Vol. II, pp. 1323-1345. Little, Brown, Boston.
MacSween, J. M., Warner, N. L., Bankhurst, A. D., and Mackay, I. R. (1927). Carcinoembryonic antigen in whole serum. Brit. J. Cancer, 26, 356-360.

MacSween, J. M., Warner, N. L., and Mackay, I. R. (1973), The detection of carcinoembryonic antigen in whole serum from patients with malignant and non-malignant disease. Clin. Immunol. Immunopathol., in press.

Moore, T. L., Dhar, P., Zamcheck, N., Keeley, A., Gottlieb, L., and Kupchik, H. Z. (1972). Carcinoembryonic antigen(s) in liver disease. 1. Clinical and morphological studies. Gastroenterology, 63, 88-94.

Moore, T. L., Kupchik, H. Z., Marcon, N., and Zamcheck, N. (1971) Carcinoembryonic antigen assay in cancer of the colon and pancreas and other digestive tract disorders. Amer. J. dig. Dis., 16, 1-7.

Reynoso, G., Chu, T. M., Holyoke, D., Cohen, E., Nemoto, T., Wang, J. J., Chuang, J., Guinan, P., and Murphy, G. P. (1972). Carcinoembryonic antigen in patients with different cancers. J. Amer. med. Ass., 220, 361-365.

Sorokin, J. J., Kupchik, H. Z., Zamcheck, N., and Dhar, P. (1972). A clinical comparison of two radioimmunoassays for carcinoembryonic antigen (CEA). Immunol. Commun., 1, 11-24.

Thomson, D. M. P., Krupey, J., Freedman, S. O., and Gold, P. (1969). The radioimmunoassay of circulating carcinoembryonic antigen of the human digestive system. Proc. nat. Acad. Sci. (Wash.), 64, 161-167.

Warner, N. L., Khoo, S. K., MacSween, J. M., Bankhurst, A. D., and Mackay, I. R. (1973). A microradioimmunoassay for carcinoembryonic antigen in whole serum and tissues. In Host Environment Interactions in the Aetiology of Cancer in Man I.A.R.C. Scientific Publications. (In press.)

Zamcheck, N., Moore, T. L., Dhar, P., and Kupchik, H. (1972). Immunologic diagnosis and prognosis of human digestivetract cancer: carcinoembryonic antigens. New Engl. J. Med., 286, 83-86. 